\title{
Review
}

\section{Chemical Sensitization of Apoptosis Induced by Hyperthermia}

\author{
KIYOSHI TANABE ${ }^{1}$, HIROYOSHI YUKI ${ }^{2}$, QING-LI ZHAO ${ }^{1}$, FU-JUN LI', \\ YOKO ARAI ${ }^{3}$, KEISUKE KAMEDA ${ }^{4}$ and TAKASHI KONDO ${ }^{*}$
}

\author{
'Department of Radiological Sciences, Faculty of Medicine, Toyama Medical and Pharmaceutical \\ University, Toyama 930-0194, Japan \\ ${ }^{2}$ Department of Obstetrics and Gynecology, Tonami General Hospital, Toyama 939-1395, Japan \\ ${ }^{3}$ Department of Public Health, Faculty of Medicine, Toyama Medical and Pharmaceutical \\ University, Toyama 930-0194, Japan \\ ${ }^{4}$ Department of Radiology, Faculty of Medicine, Toyama Medical and Pharmaceutical University, \\ Toyama 930-0194, Japan
}

\begin{abstract}
Hyperthermia (HT) has been recognized as an effective and attractive tool in anticancer therapy. However, the results obtained in therapy by HT alone have been only partially satisfactory. Consequently, attention has focused on the search for substances able to sensitize tumor cells to the damage caused by HT without reducing the capacity of normal cells. It has been reported that the tumor cell death in HT is mediated by apoptosis. Activation of a preprogrammed cascade of molecular events will result in DNA degradation and nuclear fragmentation, leading to apoptosis. However, the pathways which can induce apoptosis varies in different cells. If we could discover common stimuli which could induce apoptosis in all types of cells, we would obtain a new anticancer therapy against all types of tumor cells. In this report, we overviewed both mechanisms of HT-induced apotosis, and the substances used to enhance HT-induced apoptosis. Moreover, we provide evidence for the role of intracellular $\mathrm{Ca}^{2+}$ concentration in HT-induced apoptosis.
\end{abstract}

Key Words: hyperthermia, apoptosis, sensitizer, intracellular $\mathrm{Ca}^{2+}$ concentration, free radical

\section{Overview of Apoptosis Induced by Hyperthermia}

HT has been recognized as an effective and attractive tool in anticancer therapy. However, little has been reported regarding the detailed mechanism of HT-induced anticancer effects "). It has been reported that tumor cell death in mild HT is mediated by apoptosis ${ }^{2-5)}$. Apoptosis is a suicidal mode of cell death, which is of critical importance for proper ontogeny and tissue homeostasis, as well as in the pathogenesis of a variety of diseases, including cancer. It represents the most frequent type of cell response to antineoplastic chemotherapy and radiotherapy ${ }^{6}$.

The effectiveness of HT as an inducer of apoptosis has been reported ${ }^{7-13)}$, but little is known about the biochemical events underlying this phenomenon ${ }^{14}$. It is evident that activation of a preprogrammed cascade of molecular events will result in DNA degradation and nuclear fragmentation, leading to cell Received 20 November 2000. *Corresponding author, Tel: 81-76-434-7265; Fax: 81-76-434-5190; E-mail address: kondot@ms.toyamampu.ac.jp 
death ${ }^{15}$. The fate of a cell is determined by multiple genes. One group of gene products may promote apoptosis such as p53 ${ }^{16}$, whereas another group may induce survival, such as $b c l-2$ family genes ${ }^{17)}{ }^{18}$. Therefore, the final outcome of a trigger such as HT may be dependent on a balance between induction and reduction of various gene products.

\section{(a) Bax and the Bcl-2-dependent pathway}

It has been reported that DNA-damaging agents, such as ionizing radiation, induce nuclear accumulation of wild-type 533 protein and, in some cases, can cause apoptosis ${ }^{19}$. Van Bree et al. studied the thermal response of transfectants of a human colon carcinoma cell line RKO, in which the function of p53 and of its down-stream effector in the $\mathrm{G}_{1}$ arrest $\mathrm{pRb}$ were functionally inactivated ${ }^{20)}$. Recently, it was reported that transfection of wild-type p53 into fibroblasts derived from p53-knockout mice enhanced thermal sensitivity and accelerated the apoptotic response ${ }^{21}$. These results show that the $p 53$ gene is a factor in determining cellular thermosensitivity, and that wild-type $p 53$ contributes to thermosensitization resulting in enhancement of heat-induced apoptosis.

The role of p53 lies in its changing the balance of the two gene expressions. The p53 protein downregulates $b c l-2$ and up-regulates bax expression ${ }^{18}$. Fuse et al. indicated that heat-induced apoptosis in A172 cells was accompanied by augmentation of the p53 protein, bax mRNA and protein ${ }^{22}$. Similar results were obtained in an other observation of bax expression using a cell line transfected with an expression plasmid encoding a temperature-sensitive version of $\mathrm{p} 53^{23)}$. Thus, these results suggest that the molecular mechanism which mediates heat-induced, p53-dependent apoptosis is the up-regulation of bax expression.

It has been demonstrated that $b c l-2$ and $b a x$ genes and their family members are intimately involved in the regulation of apoptosis induced by various stimuli ${ }^{24-26)}$. The effect of $b c l-2$ seems to be inhibitory, whereas bax expression seems to be required for the initiation of apoptosis. HT is in fact a powerful apoptotic inducer in HL-60 and U937 cells, which scarcely express antiapoptotic genes. On the contrary, the antiapoptotic $b c l-2$ and bcr-abl genes, widely expressed in DoHH2 and K562 cells, respectively, are concomitant with very low apoptosis triggering or to strong cell resistance, as reported by a number of authors ${ }^{27-30)}$. One of the reported functions of Bcl-2 is inhibition of the activation of ICE-Iike cysteine proteases such as caspase 3, which is responsible for PARP cleavage ${ }^{31}$. Furlong et al. demonstrated that intracellular acidification triggered apoptosis by directly or indirectly activating ICE-like proteases, while Bcl-2 overexpression delayed intracellular acidification and inhibited ICE-Iike protease activation ${ }^{32}$.

\section{(b) Bax and the Bcl-2-independent pathway}

On the other hand, Takasu et al. suggested the existence of apoptotic pathways independent of Bcl-2 ${ }^{33}$. They observed the cleavage of poly (ADP-ribose) polymerase (PARP) in HL-60 cells after heating, particularly in those cells heated in a medium of $\mathrm{pH}$ 6.6, despite the lack of change in the expression of the Bcl-2 and Bax proteins. The optimal $\mathrm{pH}$ for PARP cleavage by caspase 3 is $\mathrm{pH} 6.5-7.0^{34}$. It is therefore probable that heating HL-60 cells in a pH 6.6 environment directly increased the proteolytic cleavage of PARP mediated by caspases without the involvement of upstream factors, i.e., Bcl-2 and Bax, and triggered the downstream reaction, e.g., fragmentation of DNA. Cleavage of PARP may lead to activation of the endonuclease responsible for DNA fragmentation in apoptosis ${ }^{35}$. It is also probable that the acidic 
environment activates the endonuclease itself ${ }^{36}$. Recently, Pena et al. suggested that environmental stresses such as ionizing radiation, ultraviolet radiation, $\mathrm{H}_{2} \mathrm{O}_{2}$, and heat shock act directly on membranes and activate acid $\mathrm{pH}$-dependent sphingomyelinase, generating ceramide and initiating signaling through a stress-activated protein kinase/c-jun-NH2-kinase pathway, leading to the activation of ICE/CED-3 proteases ${ }^{37}$. Therefore, the increase in heat-induced PARP cleavage in the $\mathrm{pH} 6.6$ environment in their study may be attributed to the synergistic effect of acidic stress and heat shock activating acid $\mathrm{pH}$ dependent sphingomyelinase, thereby activating ICE/CED-3 proteases. A temporal relationship between protein phosphatase, ICE/CED-3 proteases, intracellular acidification, and DNA fragmentation in apoptosis has been also proposed ${ }^{38}{ }^{39}$.

Katschinski et al. provided evidence for an autocrine effect of endogenously produced TNF- $\alpha$ that was responsible for heat-induced apoptosis in non-differentiated PLB-985 cells ${ }^{40}$. The ability to undergo heatinduced apoptosis was lost in neutrophilic-differentiated PLB-985 cells, which appeared to be related to the lack of heat-inducible TNF- $\alpha$ expression in differentiated cells. TNF- $\alpha$-dependent apoptosis in nondifferentiated PLB-985 cells was mediated via the p55 TNF- $\alpha$ receptor. The expressions of Bcl-2 and Bax did not change after heat exposure, which implies that the heat-induced apoptotic process is independent of Bcl-2 or Bax. Heat-induced TNF- $\alpha$ mRNA expression and apoptosis were prevented by the addition of PDTC, which is able to block nuclear factor $\kappa \mathrm{B}$ activity by inhibition of reactive oxygen species formation. It is tempting to speculate that reactive oxygen intermediates are involved in the induction of TNF- $\alpha$ expression by heat. In general, TNF- $\alpha$-induced effects are mediated by the 555 and p75 TNF receptors. Only the p55 receptor contains the intracellular death domain, which is critically important for recruiting several proteins involved in the TNF- $\alpha$-mediated apoptotic program ${ }^{41}{ }^{42}$. Previous studies have shown that similar TNF- $\alpha$-mediated self-inflicted apoptotic pathways play a significant role as negative feedback mechanisms which regulate the natural killer cell immune response after maximal stimulation with interleukin 12 and interleukin $15^{43}{ }^{44)}$. Autocrine suicidal effects have also been demonstrated for other apoptotic death factors, such as the FAS ligand ${ }^{45}$.

\section{(c) Reactive oxygen species (ROS) and HT-induced apoptosis}

It has been repeatedly shown that HT can induce oxidative stress in tissues because of increased production of ROS and/or promotion of cellular oxidation events ${ }^{46-50}$. Such an increased formation of ROS during HT can become a further major mechanism of cell injury and could in principle be exploited in hyperthermic cancer treatments ${ }^{46}$. ROS are in fact cytotoxic and have been shown to kill cells via apoptosis ${ }^{51}$. In liver tissue exposed to hyperthermic perfusion, several markers of oxidative injury have determined, including the oxidation and depletion of reduced glutathione ${ }^{48}$ and the appearance of aldehydic products of lipid peroxidation ${ }^{49}$, 50).

In some studies, the activation of tissue xanthine dehydrogenase to its oxidase form has been implicated as a major mechanism in the oxidative stress caused by $\mathrm{HT}^{46)}{ }^{47}$. Indeed, HT has been shown to induce xanthine oxidase (XO) activation ${ }^{46)}{ }^{47)}$, and it is known that the interaction of XO with its substrate (hypoxanthine) is associated with the generation of a superoxide anion as a by-product. $\mathrm{XO}^{52}$ and hypoxanthine concentrations ${ }^{53)}$ are elevated in tumor tissues because of impaired energy metabolism leading to accumulation of ADP, as well as to degradation of nucleic acids after cell death, thus prompting the conditions for the production of significant amounts of superoxide during the $\mathrm{XO}$ reaction. The 
superoxide dismutation product, hydrogen peroxide, is a well-established apoptotic agent ${ }^{51}$. On the other hand, the reaction of reactive oxygen species with low molecular weight iron complexes could easily result in the onset of lipid peroxidation ${ }^{54}$, and indeed the release of such iron complexes is likely to occur during disaggregation of dead cells.

Autologous bone-marrow transplantation (ABMT) is widely used in the treatment of acute leukemias when a matched sibling donor is not available for allogeneic transplantation. In addition, there is no age restriction to its application, and morbidity and mortality are greatly reduced by the lack immunobiological effects of allogeneic grafts. A major drawback in the use of ABMT is the possibility that tumor cells reinfused with autologous marrow may contribute to a relapse ${ }^{55}$. Thus, ex vivo purging may be very important in preventing relapses after transplantation ${ }^{55-577}$. A growing body of data indicates that HT could be used to purge residual leukemic progenitors from remission bone marrow or peripheral blood before transplantation ${ }^{58}{ }^{59)}$, since leukemic progenitors are much more sensitive than normal hematopoietic progenitors to $\mathrm{HT}^{60-(22)}$. However, the results obtained by $\mathrm{HT}$ alone have been only partially satisfactory. Consequently, attention has focused on the search for substances able to sensitize tumor cells to the damage caused by HT, without reducing the capacity of normal hematopoietic progenitors to reconstitute hemopoiesis ${ }^{63)(64)}$.

\section{Sensitization of HT-induced apoptosis by an inhibitor of HSP expression}

It has been shown that the expression of human HSP-70 confers heat resistance to leukemic cells and solid tumors, suggesting that HSP-70 has a protective function against thermal stress ${ }^{65)}{ }^{66)}$. Furthermore, overexpression of the human $h s p-70$ gene reduces, whereas expression of the human c-myc proto-oncogene enhances, heat-induced apoptosis ${ }^{677}$. Thus, substances able to inhibit the expression of HSP-70 could be important in enhancing the killing effect of HT.

Kim et al. reported that quercetin, one of the most widely distributed bioflavonoids in the plant kingdom, acted as an HT sensitizer in HeLa cells by inducing intracellular lactate accumulation and acidification ${ }^{68}$. Osman et al. also showed that quercetin significantly synergized the killing effect of HT on K562 and KU812 Ieukemic cell lines ${ }^{69}$. Moreover, quercetin is able to inhibit the heat-dependent overexpression of HSP-70 in myeloid- and lymphoid-leukemia cell lines, and to increase the number of leukemic cells undergoing apoptosis $\left.{ }^{65)} 70\right)$.

According to the observations of Chant et al. ${ }^{71)}$, acute myeloid leukemia (AML) blasts constitutively express varying amounts of cytoplasmic HSP-70, while acute lymphoid leukemia (ALL) blasts express barely detectable levels. Larocca $e t$ al. found that quercetin inhibited the heat-induced expression of HSP70 in AML and ALL blasts, both at the protein and mRNA levels ${ }^{4}$. Kinetic experiments revealed that quercetin inhibited heat-induced HSP-70, that this inhibitory effect appeared rapidly, and persisted for up to $24 \mathrm{~h}$ after treatment. Furthermore, there was good temporal correlation between the appearance of quercetin's inhibitory effect on heat-induced HSP-70 expression and the cell-killing action of the combined treatment with quercetin and HT.

Normal bone marrow or peripheral blood CD34+ cells did not express HSP-70 constitutively, and thermic shock induced large amounts of this protein in these cells. The heat-dependent up-regulation of HSP-70 in CD34+ cells was not inhibited by the presence of quercetin during HT. On the other hand, 
these normal hematopoietic progenitors were resistant to the growth-inhibitory effect of quercetin ${ }^{72}$. The resistance of hematopoietic progenitors to combined treatment with HT and quercetin was probably due to the protective effect of HSP-70 not being modified by quercetin. As a consequence, heat-dependent apoptosis was much less marked in CD34+ cells than in leukemic blasts or more committed hemopoietic cells. In addition, the LTC-IC (long-term culture-initiating cell) population, representing the most primitive sub-set of hematopoietic progenitors ${ }^{73}$, appeared totally resistant to combined treatment with HT and quercetin. Unlike normal CD34+ cells, CD34+ leukemic blasts were sensitive to the combined treatment in terms of inhibition both of HSP-70 expression, and of clonogenic capacity. This difference in sensitivity between normal and leukemic progenitors could be a useful biological tool to definite an optimal purging protocol that would eliminate leukemic progenitors while preserving sufficient normal hematopoietic progenitors to permit long-term recovery.

\section{Sensitization of HT-induced apoptosis by free radical initiators}

Recently, we found that 2,2 -azobis(2-amidinopropane) dihydrochloride (AAPH), which is a temperature-dependent free radical generator ${ }^{74)}{ }^{75}$, enhanced the apoptosis induced by HT in U937 lymphoma cells. The effects of HT on both lipid peroxydation (LPO), which was measured by the level of 2-thiobarbioturic acid and malondialdehyde, and intracelluar $\mathrm{Ca}^{2+}$ concentration $\left(\left[\mathrm{Ca}^{2+}\right] \mathrm{i}\right)$, were enhanced markedly by the combination with AAPH. HT combined with AAPH also led to loss of mitochondrial membrane potential $(\triangle \Psi \mathrm{m})$, indicating the function of the mitochondria was also damaged during this treatment. Although an intracellular $\mathrm{Ca}^{2+}$ ion chelator, BAPTA-AM, completely inhibited the DNA fragmentation induced by the combined treatment, a water-soluble vitamin E, Trolox, only partially suppressed DNA fragmentation and the increase in $\left[\mathrm{Ca}^{2+}\right] \mathrm{i}$ In contrast, LPO was inhibited completely by Trolox, but no inhibition by BAPTA-AM was found. Of considerable interest is that addition of antioxidants could not effectively inhibit loss of $\triangle \Psi \mathrm{m}$, indicating LPO and loss of $\triangle \Psi \mathrm{m}$ appear to be independent features (Fig. 1). These results indicated the increase in $\left[\mathrm{Ca}^{2+}\right] \mathrm{i}$ is the key event in the apoptosis of U937 cells induced by HT with AAPH, though LPO plays a partial role in this apoptois.

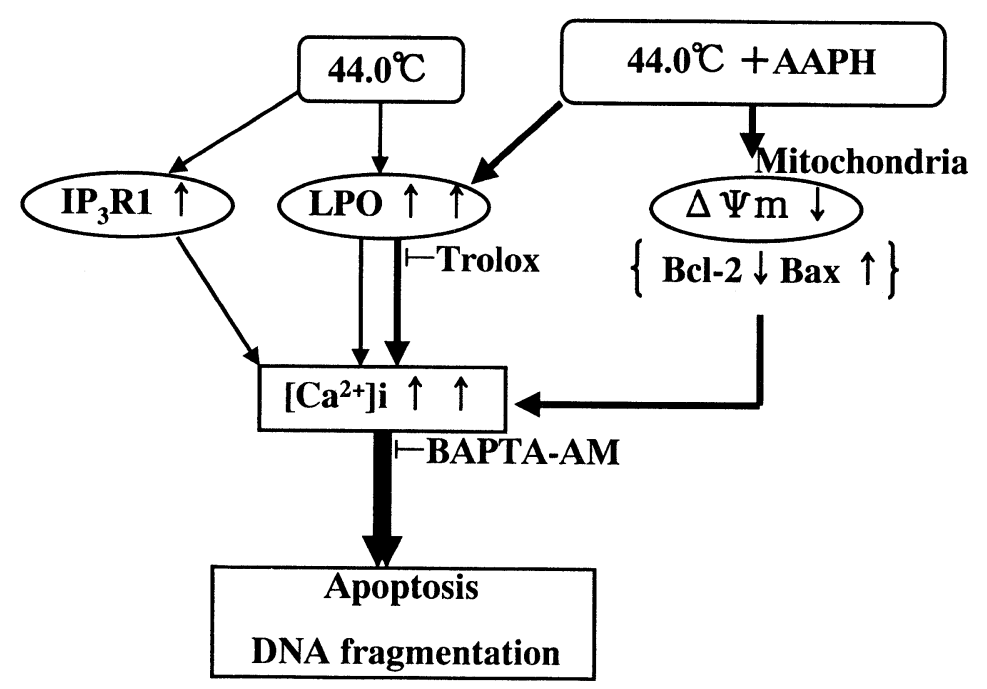

Fig. 1. Schema of hyperthermia-induced apoptosis sensitization by AAPH in U937 cells. 
The relationship between loss of $\triangle \Psi \mathrm{m}$ and the increase in $\left[\mathrm{Ca}^{2+}\right]$ i remains elusive. $\triangle \Psi \mathrm{m}$ represents the electrochemical forces used for ATP synthesis, as well as for other metabolic activities, including the maintenance of $\mathrm{Ca}^{2+}$ homeostasis within the mitochondria ${ }^{26)}$. Due to the energy requirements of the different $\mathrm{Ca}^{2+}$ transport systems that control $\mathrm{Ca}^{2+}$ homeostasis, the loss of $\triangle \Psi \mathrm{m}$ and subsequent ATP depletion invariably result in the disruption of intracellular $\mathrm{Ca}^{2+}$ homeostasis, potentially triggering a series of $\mathrm{Ca}^{2+}$ - dependent events that ultimately lead to cell death.

\section{Sensitization of HT-induced apoptosis by inhibitors of $\mathrm{Ca}^{2+}$ metabolism}

Verapamil is pharmacologically classified as a calcium channel blocker, and has been commonly used to treat arrhythmia and angina pectoris. Verapamil also has other pharmacological actions, such as reversing multiple-drug resistance for vincristine ${ }^{77)}$ and other anticancer agents ${ }^{78}$, and suppressing metastasis of cancer cells in BALB/c mice injected with mouse mammary adenocarcinoma F3II cells ${ }^{79}$. Additionally, Coss et al. ${ }^{80}$ found that verapamil acts as a hyperthermic sensitizer in Chinese hamster ovary cells exposed to HT.

We observed that combined treatment with nontoxic verapamil enhanced the DNA fragmentation and increase in $\left[\mathrm{Ca}^{2+}\right] \mathrm{i}$ induced by HT in U937 cells (unpublished data). This enhancement was observed in both normal and thermotolerant U937 cells. The number of cells containing higher $\left[\mathrm{Ca}^{2+}\right] \mathrm{i}$ (more than 200 $\mathrm{nM}$ ) was significantly increased by HT, and further elevated by the addition of verapamil in both normal and thermotolerant cells. Moreover, when the intracellular $\mathrm{Ca}^{2+}$ chelator, BAPTA-AM, was used, it inhibited DNA fragmentation in a dose-dependent-fashion. These results indicate that $\left[\mathrm{Ca}^{2+}\right] \mathrm{i}$ plays a major role in the regulation of prompt apoptosis induced by HT in U937 cells. Regulation of apoptosis by $\left[\mathrm{Ca}^{2+}\right] \mathrm{i}$ appears to be universal for HT-treated cells.

\section{Conclusion}

The clinical application of HT has a strong biological rationale. Further elucidation of the molecular mechanisms responsible for the enhancement of heat-induced apoptotic cell death may provide a rational basis for the effective use of HT and HT-induced apoptosis sensitizers in cancer therapy.

\section{References}

1) Winter A., Laing J., Paglione R., Sterzer F.: Microwave hyperthermia for brain tumors. Neurosurgery, 17: 387-399, 1985.

2) Sellins K.S., Cohen J.J.: Hyperthermia induces apoptosis in thymocytes. Radiat Res, 126: 88-95, 1991.

3) Yonezawa M., Otsuka T., Matsui N., Tsuji H., Kato K.H., Moriyama A., Kato T.: Hyperthermia induces apoptosis in malignant fibrous histiocytoma cells in vitro. Int J Cancer 66: 347-351, 1996.

4) Larocca L. M., Ranelletti F. O., Maggiano N., Rutela S., La Barbera E.O., Rumi C., Serra F., Voso M.T., Piantelli M., Teofili L., Leone G.: Differential sensitivity of leukemic and normal hematopoietic progenitors to the killing effect of hyperthermia and quercetin used in combination: role of heat-shock protein-70. Int J Cancer, 73: 75-83, 1997.

5) Gorczyca W., Gong J., Ardelt B., Traganos F., Darzynkiewicz Z.: The cell cycle-related differences in susceptibility of HL-60 cells to apoptosis induced by various antitumor agents. Cancer Res, 53: 3186-3192, 1993.

6) Williams G.T., Smith C.A.: Molecular regulation of apoptosis: genetic controls on cell death. Cell, 74: 777-779, 1993.

7) Nosseri C., Coppola S., Ghibelli L.: Possible involvement of poly(ADP-ribosyl) polymerase in triggering stress- 
induced apoptosis. Exp Cell Res, 212: 367-373, 1994.

8) Edwards M.J., Walsh D.A., Li Z.: Hyperthermia, teratogenesis and the heat shock response in mammalian embryos in culture. Int J Dev Biol, 41: 345-358, 1997.

9) Nakano H., Kurihara K., Okamoto M., Tone S., Shinohara K.: Heat-induced apoptosis and p53 in cultured mammalian cells. Int J Radiat Biol, 71: 519-529, 1997.

10) O'Neill K.O., Fairbairn D.W., Smith M.J., Poe B.S.: Critlcal parameters influencing hyperthermia-induced apoptosis in human lymphoid cell lines. Apoptosis, 3: 369-375, 1998.

11) Dyson J.E.D., Simmons D.M., Daniel J., McLaughlin J.M., Quirke P., Bird C.C.: Kinetic and physical studies of cell death induced by chemotherapeutic agents or hyperthermia. Cell Tissue Kinet, 19: 311-324, 1986.

12) Kravtsov V.D., Fabian I.: Automated monitoring of apoptosis in suspension cell cultures. Lab Invest, 74: 557-570, 1996.

13) Ghibelli L., Nosseri C., Oliverio S., Piacentini M., Autuori F.: Cycloheximide can rescue heat-shocked L cells from death by blocking stress-induced apoptosis. Exp Cell Res, 201: 436-443, 1992.

14) Laszlo A.: The effects of hyperthermia on mammalian cell structure and functlon. Cell Prolif, 25: 59-87, 1992.

15) Barinaga M.: Death by dozens of cuts. Science, 280: 32-34, 1998.

16) Wang Y., Okan I., Szekely L., Klein G., Wiman K.G.: bcl-2 inhibits wild-type p53-triggered apoptosis but not G1 cell cycle arrest and transactivation of WAF1 and bax. Cell Growth Differ, 6: 1071-1075, 1995.

17) Yin X. M., Oltvai Z. N., Korsmeyer S.: BHI and BH2 domains of Bcl-2 are required for inhibition of apoptosis and heterodimerization with Bax. Nature, 369: 321-323, 1994.

18) Selvakumaran M., Lin H.K., Miyashita T., Wang H.G., Krajewski S., Reed J.C., Hoffman B., Liebermann D.: Immediate early up-regulation of bax expression by p53 but not TGF beta 1: a paradigm for distinct apoptotic pathways. Oncogene, 9: 1791- 1798, 1994.

19) Lowe S.W., Ruley H.E., Jacks T., Houseman D.E.: p53-dependent apoptosis modulates the cytotoxicity of anticancer agents. Cell, 74: 957-967, 1993.

20) van Bree C., van der Maat B., Ceha H. M., Franken N. A. P., Haveman J., Bakker P. J. M.: Inactivation of p53 and of $\mathrm{pRb}$ protects human colorectal carcinoma cells against hyperthermia-induced cytotoxicity and apoptosis. J Cancer Res Clin Oncol, 125: 549- 555, 1999.

21) Matsumoto H., Takahashi A., Wang X., Ohnishi K., Ohinishi T.: Transfection of p53-knockout mouse fibroblasts with wild-type p53 increases the thermosensitivity and stimulates apoptosis induced by heat stress. Int $\mathbf{J}$ Radiat Oncol Biol Phys, 39: 197-203, 1997.

22) Fuse T., Yoon K.W., Kato T., Yamada K.: Heat-induced apoptosis in human glioblastoma cell line A172. Neurosurgery, 42: 843-849, 1998.

23) Miyashita T., Krajewski S., Krajewska M., Wang H.G., Lin H.K., Liebermann D.A., Hoffman B., Reed J.C.: Tumor suppresser p53 is a regulator of bcl-2 and bax gene expression in vitro and in vivo. Oncogene, 9: 1799-1805, 1994.

24) Chen M., Quintans J., Fuks Z., Thompson C., Kufe D.W., Weichselbaum R.R.: Suppression of Bcl-2 messenger RNA production may mediate apoptosis after ionizing radiation, tumor necrosis factor $\alpha$, and ceramide. Cancer Res, 55: 991- 994, 1995.

25) Sakakura C., Sweeney E. A., Shirahama T., Igarashi Y., Hakomori S., Nakatani H., Tsujimoto H., Imanishi T., Ohgaki M., Ohyama T., Yamazaki J., Hagiwara A., Yamaguchi T., Sawai K., Takahashi T.: Overexpression of bax sensitizes human breast cancer MCF-7 cells to radiation-induced apoptosis. Int J Cancer, 67: 101-105, 1996.

26) Zhong L.T., Sarafian T., Kane D.J., Charles A. C., Mah S.P., Edwards R.H., Bredesen D.E.: bcl-2 inhibits death of central neural cells induced by multiple agents. Proc Natl Acad Sci USA, 90: 4533- 4537, 1993.

27) Falcieri E., Luchetti F., Burattini S., Canonico B., Santi S., Papa S.: Lineage-related sensitivity to apoptosis in human tumor cells undergoing hyperthermia. Histochem Cell Biol, 113: 135-144, 2000.

28) Kluin-Nelemans H.C., Limpens J., Meerabux J., Beverstock G.C., Jansen J.H., de Jong D., Kluin P.M.: A new nonHodgkin's B-cell line (DoHH2) with a chromosomal translocation t(14;18)(q32;q21). Leukemia, 5: 221-224, 1991.

29) Amarante-Mendes G.P., McGahon A.J., Nishioka W.K., Afar D.E., Witte O.N., Green D.R.: Bcl-2-independent BcrAbl-mediated resistance to apoptosis: protection is correlated with up-regulation of Bcl-xL. Oncogene, 16: 1383$1390,1998$.

30) Luchetti F., Gregorini A., Papa S., Burattini S., Canonico B., Valentini M., Falcieri E.: The K562 chronic myeloid 
leukemia cell line undergoes apoptosis in response to interferon- $\alpha$. Haematologica, 83: 974-980, 1998.

31) Smyth M.J., Perry D.K., Zhang J., Poirier G.G., Hannun Y.A., Obeid L.M.: prICE: a downstream target for ceramide-induced apoptosis and for the inhibitory action of Bcl-2. Biochem J, 316: 25-28, 1996.

32) Furlong I.J., Ascaso R., Rivas A.L., Collins M.K.L.: Intracellular acidification induces apoptosis by stimulating ICE-like protease activity. J Cell Sci, 110: 653-661, 1997.

33) Takasu T., Lyons J.C., Park H.J., Song C.W.: Apoptosis and perturbation of cell cycle progression in an acidic environment after hyperthermia. Cancer Res, 58: 2504-2508, 1998.

34) Nicholson D.W., Ali A., Thornberry N.A., Vaillancourt J.P., Ding C.K., Gallant M., Gareau Y., Griffin P.R., Labelle M., Lazebnik Y.A., Munday N.A., Raji S.M., Smulson M.E., Yamin T.T., Yu V.L., Miller D.K.: Identification and inhibition of the ICE/CED-3 protease necessary for mammalian apoptosis. Nature, 376: 37-43, 1995.

35) Yoshihara K., Tanigawa Y.K., Burzio L., Koide S.S.: Evidence for adenosine diphosphate ribosylation of Ca ${ }^{2+}$, $\mathrm{Mg}^{2+}$-dependent endonuclease. Proc Nat Acad Sci USA, 72: 289-293, 1975.

36) Park H.J., Makepeace C.M., Lyons J.C., Song C.W.: Effect of intracellular acidity and ionomycin on apoptosis in HL-60 cells. Eur J Cancer, 32A: 540-546, 1996.

37) Pena L.A., Fuks Z., Kolesnick R.: Stress-induced apoptosis and sphingomyelin pathway. Biochem Pharmacol, 53: 615-621, 1997.

38) Wolf C.M., Reynolds J.E., Morana S.J., Eastman A.: The temporal relationship between protein phosphatase, ICE/CED-3 proteases, intracellular acidification, and DNA fragmentation in apoptosis. Exp Cell Res, 230: 22-27, 1997.

39) Morana S.J., Wolf C.M., Li J., Reynolds J.E., Brown M.K., Eastman A.: The involvement of protein phosphatases in the activation of ICE/CED-3 protease, intracellular acidification, DNA digestion, and apoptosis. J Biol Chem, 271:18263-18271, 1996.

40) Katschinski D.M., Ian Robins H., Schad M., Frede S., Fandrey J.: Role of tumor necrosis factor $\alpha$ in hyperthermiainduced apoptosis of human leukemia cells Cancer Res, 59: 3404-3410, 1999.

41) Tartaglia L.A., Ayres T.M., Wong G.H.W., Goeddel D.V.: A novel domain within the $60 \mathrm{kD}$ TNF receptor signals cell death. Cell, 74: 845-853, 1993.

42) Vandenabeele P., Declercq W., Beyaert R., Fiers W.: Two tumor necrosis factor receptors: structure and function. Trends Cell Biol, 5: 392-395, 1995.

43) Jewett A., Cavalcanti M., Bonavida B.: Pivotal role of endogenous TNF- $\alpha$ in the induction of functional inactivation and apoptosis in NK cells. J Immunol, 159: 4815-4822, 1997.

44) Ross M.E., Caliguri M.A.: Cytokine-induced apoptosis of human natural killer cells identifies a novel mechanism to regulate the innate immune response. Blood, 89: 910-918, 1997.

45) Friesen C., Herr I., Krammer P.H., Debatin, K.M.: Involvement of the CD95 (APO-1/FAS) receptor/ligand system in drug-induced apoptosis in leukemia cells. Nat Med, 2: 574-577, 1996.

46) Skibba J.L., Quebbeman E.J., Kalbfleisch J.H.: Nitrogen metabolism and lipid peroxidation during hyperthermic perfusion of human livers with cancer. Cancer Res, 46: 6000-6003, 1986.

47) Lin P.S., Quamo S., Ho K.C., Gladding J.: Hyperthermia enhances the cytotoxic effects of reactive oxygen species to Chinese hamster cells and bovine endothelial cells in vitro. Radiat Res, 126: 43- 51, 1991.

48) Powers R.H., Stadnicka A., Kalbfleish J.H., Skibba J.L.: Involvement of xanthine oxidase in oxidative stress and iron release during hyperthermic rat liver perfusion. Cancer Res, 52: 1699-1703, 1992.

49) Yoshikawa T., Kokura S., Tainaka K., Itani K., Oyamada H., Kaneko T., Naito Y., Kondo M. The. role of active oxygen species and lipid peroxidation in the antitumor effect of hyperthermia. Cancer Res, 53: 2326-2329, 1993.

50) Skibba J.L., Gwartney E.A.: Liver hyperthermia and oxidative stress: role of iron and aldehyde production. Int J Hyperthermia, 13: 215-226, 1997.

51) Buttke T.M., Sandstrom P.A.: Oxidative stress as a mediator of apoptosis. Immunol Today, 15: 7-10, 1994.

52) Kokoglu E., Belce A., Ozyurt E., Tepeler Z.: Xanthine oxidase levels in human brain tumors. Cancer Lett, 50: 179$181,1990$.

53) Wung W.E., Howell S.W.: Hypoxanthine concentrations in normal subjects and patients with solid tumors and leukemia. Cancer Res, 44: 3144-3148, 1984. 
54) Minotti G.: Sources and role of iron in lipid peroxidation. Chem Res Toxicol, 6: 134-146, 1993.

55) Gorin N.C. and 21 others: Autologous bone-marrow transplantation for acute myeloblastic leukemia in Europe: further evidence of the role of marrow purging by mafosfamide. Leukemia, 5: 896-907, 1991.

56) Vogler W.R., Berdel W.E., Olson A.C., Winton E.F., Heffner L.T., Gordon D.S.: Autologous bone-marrow transplantation in acute leukemia with marrow purged with alkyl-lysophospholipids. Blood, 80: 1423-1429, 1992.

57) Bilgrami S., Silva M., Cardoso A., Miller K.B., Ascensao J.L.: Immunotherapy with autologous bone-marrow transplantation: rationale and results. Exp Hemat, 22 : 1039-1050, 1994.

58) Herrmann R.P., O'Reilly J., Meyer B.F., Lazzaro G.: Prompt haemopoietic reconstitution following hyperthermiapurged autologous marrow and peripheral-blood-stem-cell transplantation in acute myeloid leukaemia. Bone Marrow Transplant, 10: 293-295, 1992.

59) Moriyama Y., Hashimoto S., Goto T., Furukawa T., Kishi K., Takahashi M., Shibata A.: In vitro purging of clonogenic leukemic cells from human bone marrow by heat: simulation experiments for autologous bone-marrow transplantation. Leuk Res, 16: 973- 977, 1992.

60) Robins H.I., Steeves R.A., Martin P.A., Miller K., Clark A.W., Dennis W.H.: Differential sensitivity of AKR murine leukemia and normal bone marrow cells to hyperthermia. Cancer Res, 43: 4951-4955, 1983.

61) Robins H.I., Dennis W.H., Martin P.A., Sondel P.M., Yatvin M.B., Steeves R.A.: Potentiation of differential hyperthermic sensitivity of AKR leukemia and normal bone marrow cells by lidocaine or thiopental. Cancer, 54: 2831-2835, 1984.

62) Robins H.I., Dennis W.H., Steeves R.A., Sondel R.A.: A proposal for the addition of hyperthermia to treatment regimens for acute and chronic leukemia. J Clin Oncol, 2: 1050-1056, 1984.

63) Gidali J., Feher I.: The effect of a combined purging with mafosfamlde and hyperthermia on murine haematopoietic stem cells and leukaemogenic cells. Bone Marrow Transplant, 10: 479-483, 1992.

64) Osman Y., Moriyama Y., Shibata A.: Concentration and effect of quercetin. Response Exp Hematol, 24: 495-496, 1996.

65) Wei Y.Q., Zhao X., Kariya Y., Fukata H., Teshigawara K., Uchida A.: Induction of apoptosis by quercetin: involvement of heat shock protein. Cancer Res, 54: 4952-4957, 1994.

66) Mivechi N.F., Ouyang H., Monson J.M., Hahn G.M.: Correlation of heat resistance and HSP-70A levels in human tumor cells measured by competitive quantitative polymerase chain reaction. J Radiat Oncol Phys, 30: 141-149, 1994.

67) Li W.X., Chen C.H., Ling C.C., Li G.C.: Apoptosis in heat-induced cell killing: the protective role of hsp-70 and the sensitization effect of the c-myc gene. Radiat Res, 145: 324-330, 1996.

68) Kim H.J., Kim H.S., Alfieri A.A., Young C.W.: Quercetin, an inhibitor of lactate transport and hyperthermic sensitizer of HeLa cells. Cancer Res., 44: 102-106, 1984.

69) Osman Y., Moriyama Y., Shibata A.: Enhanced elimination of $\mathrm{Ph}+$ chromosome cells in vitro by combined hyperthermia and other drugs (AZT, IFN- $\alpha$, TNF and quercetin):its application to autologous bone-marrow transplantation for CML. Exp Hematol, 23: 444-452, 1995.

70) Elia G., Santoro, M.G.: Regulation of heat-shock-protein synthesis by quercetin in human erythroleukaemia cells. Biochem J, 300: 201-209, 1994.

71) Chant I.D., Rose P.E., Morris A.G.: Analysis of heat-shock-protein expression in myeloid-leukaemia cells by flow cytometry. Brit J Haematol, 90, 163-168, 1995.

72) Larocca L.M., Teofili L., Leone G., Pierelli L., Menichella G., Scambia G., Benedetti Panici P., Ricci R., Piantelli M., Ranel-Letti F.O.: Anti-proliferative activity of quercetin on normal bone marrow and leukaemic progenitors. Brit J Haematol, 79: 562-566, 1991.

73) Udomsakdi C., Lansdorp P.M., Hogge D.E., Reid D.S., Eaves A.C., Eaves C.J.: Characterization of primitive hematopoietic cells in normal human peripheral blood. Blood, 80: 2513-2521, 1992.

74) Niki E.: Free radical initiators as source of water or lipid soluble peroxyl radicals. Meth Enzymol, 186: 100-108, 1990.

75) Krishna M.C., Dewhirst M.W., Friedman H.S., Cook J.A., Degraff W., Samuni A., Russo A., Mitchell J.B.: Hyperthermic sensitization by the radical initiator 2,2 -azobis(2-amidinopropane) dihydrochloride(AAPH). I. In vitro studies. Int J Hyperthermia, 10: 271-278, 1994. 
76) Nicotera P., Bellomo G., Orrenius S.: Calcium-mediated mechanisms in chemically induced cell death. Annu Rev Pharmacol Toxicol, 32: 449-470, 1992.

77) Tsuruo T., Iida H., Tsukagoshi S., et al.: Overcoming of vincristine resistance in P388 leukemia in vivo and in vitro through enhanced cytotoxicity of vincristine and vinblastine by verapamil. Cancer Res, 41: 1967-1972, 1981.

78) Helson L.: Calcium channel blocker enhancement of anticancer drug cytotoxicity - a review. Cancer Drug Delivery, 1: 353 -361, 1984.

79) Farias E.F., Aguirre Ghiso J.A., Ladeda V., et al.: Verapamil inhibits tumor protease production, local invasion and metastasis development in murine carcinoma cells. Int J Cancer, 78: 727- 734, 1998.

80) Coss R.A., Felgar R.E., Stokes D.G., et al.: Effect of verapamil and diltiazem on hyperthermic cell death in CHO cells. Int J Hyperthermia, 5: 383-387, 1989. 


\title{
温熱誘発アポトーシスの化学的増感 \\ 田辺清司 ${ }^{1} \cdot$ 結城浩良 ${ }^{1} \cdot$ 趙慶利 1 ·李富君 ${ }^{1} \cdot$ 荒井陽子 ${ }^{3}$ \\ 亀田圭介 ${ }^{4} \cdot$ 近藤 $\quad$ 隆 ${ }^{1}$ \\ '富山医科薬科大学医学部放射線基礎医学講座 \\ 2富山県砺波市市立砺波総合病院産婦人科 \\ 3富山医科薬科大学医学部公衆衛生学講座 \\ 4 富山医科薬科大学医学部放射線医学講座
}

\begin{abstract}
要＼cjkstart旨：温熱療法は癌治療において副作用が少なくかつ効率的な治療法となりうる可能性を秘めている が，現状の治療成績は必ずしも満足のいくものではない，それゆえ，温熱によって引き起こされる腫瘍細胞 の損傷を増感する物質の探索が注目されはじめている，温熱による腫瘍細胞の死はアポトーシスが原因であ るという報告が数多くなされている．細胞内の特定の情報伝達系が活性化されることによってアポトーシスは 誘導されるが，その伝達経路は細胞種によって異なっている，もし，すべての腫瘍細胞にアポトーシスを誘 導することのできる共通の経路をみつけだすことができれば，あらゆる癌に対抗できる新たな治療法が確立 されるであろう。本論文では、現在までに解明されている温熱誘発アポトーシスの機序および温熱誘発アポ トーシスを増強する物質について概観する．また,「すべての腫瘍細胞にアポトーシスを誘導することのできる 共通の経路」の候補のひとつとしてわれわれが注目している “細胞内 $\mathrm{Ca}^{2+}$ ”に焦点をあて, 温熱誘発アポトーシ スにはたすその役割についての最近の結果を報告する.
\end{abstract}

